\title{
Human Capital Management and Future of Work; Job Creation and Unemployment: A Literature Review
}

\author{
Adamson Mukhalipi \\ Texila American University, Lusaka, Zambia \\ Email: adamsonmukhalipi@ymail.com
}

How to cite this paper: Mukhalipi, A. (2018) Human Capital Management and Future of Work; Job Creation and Unemployment: A Literature Review. Open Access Library Journal, 5: e4859.

https://doi.org/10.4236/oalib.1104859

Received: August 21, 2018

Accepted: September 8, 2018

Published: September 11, 2018

Copyright (c) 2018 by author and Open Access Library Inc.

This work is licensed under the Creative Commons Attribution International License (CC BY 4.0).

http://creativecommons.org/licenses/by/4.0/

\section{(c) (i) Open Access}

\begin{abstract}
An enormous amount of literature has emerged over the last few years in the context of the "human capital management", "Future of Work" and on "Zambian Case: Job creation and unemployment". The existing literature on the human capital management, the future of work and the Zambian case on job creation and unemployment, covers a wide range of topics. Investment in the human capital enhances performance, employee engagement, innovation and labor productivity. However, it has been observed that the future of work; technology advancement, automation in the transportation and agriculture sector might disrupt economic and social activities in developing countries including Zambia by the year 2026. Nevertheless, despite this wealth of existing studies, some important gaps remain, which should be addressed in future research: 1) Reduction on poverty levels, little is known about the margin by which poverty levels both in rural and urban areas will be reduced by 2021 considering that technological advancements and automation are expected to alter the way of doing business in service sector: transport Sector and manufacturing sector and also the agriculture sector by 2026. 2) Development strategies on human capital development to address the challenges associated with low labor productivity and how technological advancements, automation in the service sector (transportation), manufacturing sector and agriculture sector will sustain jobs that Zambian Government will have created for the locals by the year 2026. 3) Development strategies on human capital development which will ensure that most workers which enter the labor force after dropping out of school, attain basic numeracy, ICT and literacy skills by 2026. 4) Exploring measures to address wage inequality issues in view of off loading robots and use of articial intelligences on the Zambian market which could have potential to widen the gap between highly skilled expatriates and local Zambians.
\end{abstract}




\section{Subject Areas}

Human Resource Management

\section{Keywords}

Human Capital Management, Future of Work and Automation

\section{Introduction}

Increase of environmental challenges inevitably changes our methods, challenges such as rapid change, diversity of workforce, globalization, evolution and transformation of business and family roles, lack of skills and emergence of service sector affect not only the organizational structure but also the nature and functional role of business [1]. In response to these environmental challenges and in order to increase the efficiency and effectiveness and ultimately the productivity, the organizations have shifted toward two facilitators: human capital development and innovation [1]. In this challenging global economic environment, organizations are fighting in the war of "talent to remain competitive" [2]. In this global market, companies are composed of competitors, regardless of industry [3]. However, most public institutions tend to persistently fail to deliver as expected [4]. It is therefore, suggested that organizations need to develop multi-faceted strategies such as human capital management that seek to strengthen employer and employee retention to enhance performance [4]. It is important that firms leverage on the workforce as a competitive weapon through human capital management [3]. There are many aspects of Human Capital Management that could be applied and used by human capital practitioners to ensure employee engagement and their retention in the organization [2].

Human capital management is defined as a bundle of human resource practices that provide Human Resource professionals with the resources they need to shift from reactive, task-oriented role to being a proactive strategic partner [4]. Therefore, a holistic human capital management approach requires organizations to view talent acquisition, development, retention and employee engagement in a radically new way as a single entity rather than distinct parts. Several Human Capital Management practices such as creating great work environment, encouraging positive discretionary behavior and competitive reward and also recognition have actually helped in enhancing employee engagement [2]. Employees who are engaged on the job are said to be more committed to the organization and thus build some emotional link between themselves and their employers, which in turn lead to employee retention [2].

Human capital management is not about automating processes through the use of software as this is just a clever marketing strategy by software companies and human resource professionals [4]. However, the Fourth Industrial Revolution which is focused on technological developments in robotics, artificial intel- 
ligence and genetics, might have an impact on the labor market [5]. Concretely, technology, climate change, globalization, and demography are seen as key megatrends within the context of the world of work and are projected to play a defining role in the upcoming years [5]. Therefore, understanding how these megatrends might influence work and society is crucial to prepare for the changes to come, which are expected to have an impact on job creation and unemployment rates [6].

In view of the foregoing, this paper aims at addressing the following:

a) What is human capital management and what are empirical studies supporting this?

b) How does future of work entail in terms of job creation and unemployment?

c) What are the challenges that Zambia faces as regards human capital, unemployment and job creation?

d) Summary and identified gaps are in the literature.

\section{Literature Review}

\subsection{Human Capital Management and Empirical Studies}

Various scholars and researchers have failed to come up with a consensus definition of human capital Management as of today [7]. Therefore, there is still a problem with the scientific understanding of the nature, status and the role of human capital [8]. For instance, some scholars state that Human Capital Management (HCM) is an approach to employee staffing that perceives people as assets (human capital) whose current value is measured and whose future value is enhanced through investment [9]. An organization that supports HCM, provide employees with clearly defined goals and consistently communicates performance expectations. In such organizations, the Managers are responsible for rating, rewarding and holding employees accountable for achieving specific business goals, creating innovation and supporting continuous improvement. The other scholar defines HCM as a system which organizations use to improve performance of those in critical roles such as having the biggest impact on corporate core competencies [10]. Performance improvement is attained by acquiring, training, managing, retaining employees for them to contribute effectively in the processes of the organization [8]. HCM provides decision support by combining business and workforce intelligence to the development of enterprise human capital strategies such as on how to leverage people and their ideas effectively to achieve bottom line business goals in terms of growing the business, increasing market share, margins, share price and decreasing cost, as well as improving business processes, benefiting from technology investments and increasing productivity [10]. HCM is also defined as alignment between the enormous potential provided by people with the mission and strategic objectives of the business, in order to maximize their value on behalf of the stakeholders [11]. Human Capital Management enables employees to increase performance and competi- 
tiveness of organizations by identifying and optimizing their human capital and increases the potential of human resources. HCM represents an approach when the people in an organization are regarded as wealth and investment in the future, bringing revenues [8]. Therefore, Human Capital Management is regarded as the umbrella term that comprises of three separate management disciplines: Human Asset Management, Human Cultural Management and Human Potential Management [11]. Human Asset Management predominantly covers operations 'and Human Potential Management corresponds with Human Development [11]. The HCM-activities strengthen the commitment, dedication and motivation of individual employees, while companies show an increase of their basic assets: material (financial performance), commercial, socialization and creative assets (or intellectual capital) [11].

The concept of human capital deals with added value which individuals provide to distinguish one organization from another organization and this is considered as a real competitive advantage [12]. Human capital resources are intangible but critical of the organization that put employees to the organizations [13]. Human capital consists of the intangible resources that workers provide for their employers and it represents the human factor in the organization; the combined intelligence, skills and expertise that gives the organization its distinctive character [9]. Therefore, human capital is believed to be the human agent of the organization which contains a combination of intelligence, skill and specializations that individuals are totally unique put available to the organization [12]. Organization human elements are elements that are able to learn, change, and innovate and provide the driving engine of creativity, which if appropriate to motivating, it can guarantee the long term survival of the organization [12]. Human capital is not under ownership of organizations, but can be guaranteed through the employment relationships. Individuals bring the human capital to the organization and then develop it through experience and education [13]. Human capital is accumulated knowledge, skills and abilities which can potentially help to increasing productivity and performance at work and also in life [14]. Based on this definition, the human capital can be seen as an aim for the individuals wellbeing and a fundamental tool for achieving the goals of the organization and the individual simultaneously. It could also be said as anything other than the physical capital (property, equipment, financial capital) that has an innate talent and it can also change itself and other production inputs or is modified [15]. Therefore, it is the only product agent that has the ability to create new products and to improve the production processes [15].

Human capital in economic aspect is the base of innovation, that leads to economic growth widely and from social aspect is the cornerstone of the knowledge society [16]. It is the knowledge, skills, competencies and the attributes that can be collected in individuals and in turn makes it easy to achieve personal, economic and social success. The current and dominant attitude about the human capital is that to what extent it can help the innovation of the organization. 
Innovation, which is doing new activities horizontally to all over the organization and doing new activities vertically at all levels of the organization [16].

The roots of the theory of human capital are traced from the field of macroeconomic development theory [17]. A classic book entitled, Human Capital: A Theoretical and Empirical Analysis with special reference to education, illustrates this domain, the author argues that there are different kinds of capitals that include schooling, a computer training course, expenditures on medical care [18]. Further the Author explains that lectures on the virtues of punctuality and honesty are in fact capital too as they improve health, raise earnings, or add to a person's appreciation of literature over a lifetime [18]. Consequently, it is fully in keeping with the capital concept as traditionally defined to say that expenditures on education, training, and medical care, etc., are investment in capital. These are not simply costs but investment with valuable returns that can be calculated. However, from Classical Economic Theory's perspective, labor is considered as a commodity that can be traded by way of purchase and sale. This classical theory perceives labor as something that is exploited by capital. However, contrary to the traditional meaning associated with the term labor, human capital views labor in terms of knowledge, expertise, and skill one accumulates through education and training hence the emphasis on the social and economic importance of human capital theory [18]. This is why it is noted that of all capital the organization might have, the most valuable of all capital is that investment in human being [18]. A distinction between firm-specific human capitals and general-purpose human capital is made and Firm-specific human capital is seen to include expertise obtained through education and training in management information systems, accounting procedures, or other expertise specific to a particular firm while General-purpose human capital is seen as knowledge gained through education and training in areas of value to a variety of firms such as generic skills in human resource development [18]. Regardless of the application, education and training to be the most important investment in human capital [18].

Review of literature has revealed empirical studies that have been carried out to assess the impact of Human Capital Management and its effect on performance, innovation and employee engagement as highlighted below:

- In a research study carried out in Malaysia to assess the effect of human capital on organizational performance: a literature review, the researchers noted the current decline in the various economies of the world which had resulted in human capital gaining wider importance in view of the increasing globalization and saturation of job market [19]. They observed that in order to increase the economic growth by giving more time and putting in more effort, both developed and developing countries were emphasizing on human capital development [19]. The study therefore suggested that to get into the international arena, one of the basic solutions was human capital development. For this, the firms needed to invest necessary resources for developing hu- 
man capital which had greater impact on performance [19].

- In a descriptive analytical survey which was carried out Health care organizations of Markazi Province in Iran which was aimed at assessing the role of Human Capital Development and Innovation [1]. The study revealed that human capital development, healthcare management, infrastructure of official institutions, infrastructure of unofficial institutions and knowledge (education) management development had a significance effect on innovation at significance level of $95 \%$. As a result, all research hypotheses were confirmed. The study concluded that innovation in inputs results in increased efficiency of employees especially in educational sections of the organization [1].

- A research study was carried out in Bangladesh, which was aimed at highlighting the conceptual framework of the term human capital management (HCM) and to make a case that HCM could ensure competitive advantage for an organization. The Researchers observed that the concept of human capital was concerned with the added value people provide for organizations [9]. This study emphasized that competitive advantage was achieved by strategic investments in those assets through employee engagement and retention, talent management and learning and development programmes. The result of this study highlighted that the value of human capital (HC) and its strategic activities, had an influence on organizations performance and competitive abilities [9].

- In a study entitled the role of human capital management in enhancing engagement and retention among top talent in organization: a critical literature review, it was revealed that several Human Capital Management practices such as creating great work environment, encouraging positive discretionary behavior, and competitive reward and recognition had actually helped in enhancing employee's engagement [2]. While some human capital management practices such as equitable reward package, continuous training and development programmes and fair performance appraisal significantly contributed to employees' retention in an organization [2].

\subsection{Future of Work: Job Creation and Unemployment}

The last few years have seen an emergency of enormous amount of literature that in the context of the "Future of work" which has been fuelled by Academics" think tanks and policy makers [5]. However, these rich discussions on how the future of work might look like and how this could be shaped, have failed to come up with a universally accepted definition of what exactly the "future of work" should encompass and what could be the most relevant drivers that could influence future jobs and wages [5]. In this regard, the future of work was defined along five dimensions in which current changes would impact the world of work: the number of jobs; their quality; wage and income inequality; social protection systems; and social dialogue and industrial relations (See Figure 1). 


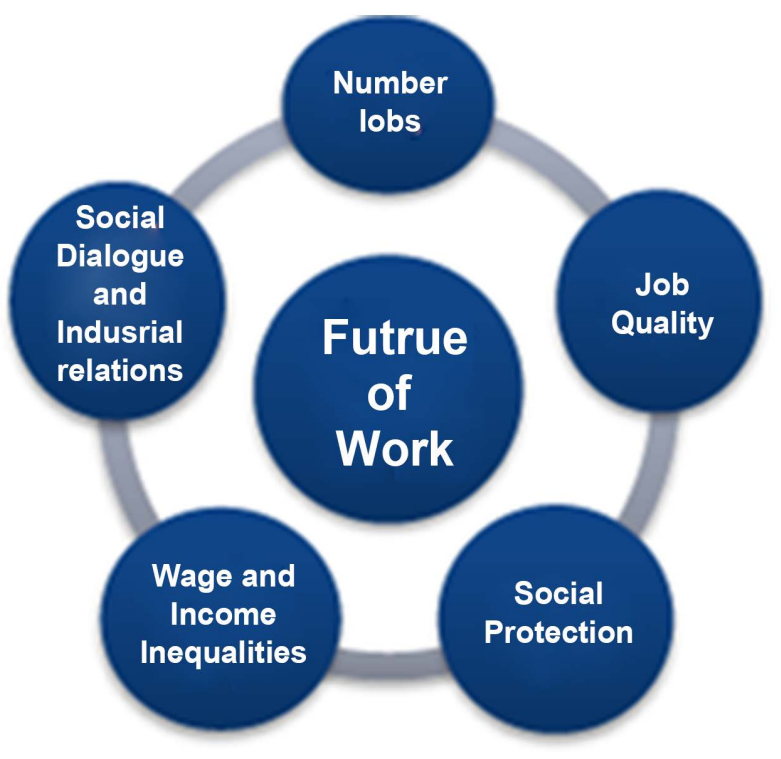

Figure 1. Outcomes of the future of work. Adapted from: [5].

However, for the purpose of this paper, the number of jobs refers to job creation, job destruction or the future composition of the labor force. The key aspect of the future of work debate has centered on whether enough jobs would be created in coming years for all those who would be seeking to work. In particular, an impassioned debate has flourished around the question: How will rapid technological change affect the number of jobs? Some engineers and technologists expect a technological transformation to be proportion with the Industrial Revolution of the 19th century [20]. Others are less convinced and believe innovation has, in fact, peaked [21]. At the same time, though, there are additional drivers of change such as climate change and demographic shifts that are also set to influence the number of jobs in the future. Most observers seem to agree on the likelihood of an acceleration job destruction under the impression of current technological changes [22] [23] [24]. In contrast, little is known about the potential for the creation of new jobs. For such new jobs to appear, many comment on the need for new markets to be developed and regulated, in particular in the green economy, care and personal services sectors, or an augmented public sector in areas where currently no profitable activities exist [12]. However, the fear is that this process might not happen fast enough. Therefore, the number of jobs might fall faster than the global labor force when existing jobs are substituted by automation and other systems operated by artificial intelligence. In other words, machines, robots and computers will increasingly have an absolute advantage over labor and not only a comparative one.

A growing body of researchers argues that technological progress in robotics and automation would lead to net job losses or lower wages as these advancements increasingly substitute for labor [20]. So far, job losses are concentrated among low- and middle-skilled (white-collar) administrative and routine jobs, such as bookkeeping, product testing and machine operators, leading to a rise in 
job polarization in advanced countries and a large number of developing economies [20]. This trend is likely to continue: The World Economic Forum (2016a), for instance, estimates that out of $96,928,000$ office and administration employees globally, 4,759,000 (4.9 per cent) would be made redundant by 2020 [20]. In a Delphi study conducted by the Bertelsmann Foundation, experts anticipate unemployment to continuously rise in both advanced and emerging economies, reaching more than 20 per cent in Europe, and over 25 per cent in Latin and North America by 2050 (see Figure 2).

The potential productivity and producer welfare gains are believed to act as a catalyst for such changes in production processes. For example, one study estimates that companies with more automated activities are 6 times more likely to experience revenue growth of more than 15 per cent compared to companies with low automation [25].

Moreover, on the basis of detailed occupations data some observers estimate that 47 per cent of total U.S. employment is at high risk of being digitalized within 20 years (Frey and Osborne, 2013). Globally, automation is estimated to affect 1.1 billion workers (49 per cent of jobs) and US $\$ 12.7$ billion in wages [24]. Furthermore, the [26] estimates as much as 66.6 per cent of jobs susceptible to be made redundant in the developing world due to technology disruption. In contrast, other studies produce much lower figures, such as only around 9 per cent of jobs are automatable in Organization for Economic Co-operation and Development (OECD) counties [23]. Nevertheless, this process of job destruction and substitution might be spread out over a long time period as a result of low wages and slow-paced implementation for example in the [27] finds that about 35 per cent of jobs might disappear due to new technologies in the next two decades. At the same time, 40 per cent of the country's employment has a low or inexistent risk of automation [27] [28] [29]. Other studies do not expect that entire occupations will disappear; rather, they argue that only some tasks are bound to be replaced by technology. In fact, [30] estimates that automation could replace 45 per cent of activities currently undertaken by humans, but only 5 per cent of full jobs could be totally substituted by technology [23]. Table 1 provides an overview of technological unemployment estimates from various institutions and researchers.

Automation might also cause jobs to be re-shored from developing countries to advanced economies [36] [37]. The increasing use of robots in developed countries together with new production techniques that demand a sophisticated level of skills will reduce labor-cost advantages of producing in developing countries [36] [37] [38]. This may lead to a displacement of employment from developing to developed countries [37]. The willingness to re-shore arises from the proximity to innovation centers and consumer markets [37]. For the same reason, though, emerging economies with high educational levels and increasing middle-classes are also targeted by international firms as a hub for production [37]. As a consequence, the likelihood that re-shoring will bring back middle-class jobs to developed economies is seen as very low, since the functions will 


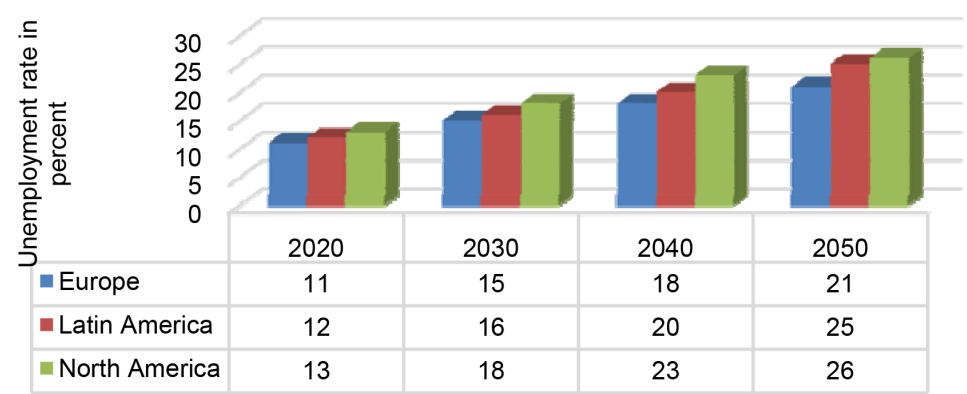

Figure 2. Expected unemployment rates [Expert Surveys].

Table 1. Estimates of technological unemployment.

\begin{tabular}{|c|c|}
\hline University of Oxford & $47 \%$ of workers in America at high risk of jobs replaced by automation \\
\hline $\begin{array}{l}\text { Price water house } \\
\text { coopers }\end{array}$ & $\begin{array}{l}38 \% \text { of jobs in America, } 30 \% \text { jobs in UK, } 21 \% \text { in Japan and } 35 \% \text { in } \\
\text { Germany at risk to automation }\end{array}$ \\
\hline ILO & ASEAN-5:56\% of jobs at risk to automation in the next 20 years \\
\hline Mckinsey & $60 \%$ of all occupations have at least $30 \%$ technically automation activities \\
\hline OECD & $\begin{array}{l}\text { OECD average } 9 \% \text { of jobs at high risk. Low risk of complete automation but } \\
\text { am important share (between } 50 \%-70 \% \text { ) of automatable tasks at risk }\end{array}$ \\
\hline Roland Berger & $\begin{array}{l}\text { Western Europe. } 8.3 \mathrm{~m} \text { jobs lost in industry against } 10 \mathrm{~m} \text { new jobs created } \\
\text { in services by } 2035\end{array}$ \\
\hline World Bank & $2 / 3$ of all jobs in developing countries are susceptible to automation \\
\hline Bruegel & EU countries between $47 \%$ and $54 \%$ of jobs are risk of automation \\
\hline
\end{tabular}

Source: [22] [26] [30]-[35].

be overtaken by automation [28] [36] [37] [38]. Job creation in the services sector is mostly under threat from automation [22], despite the earlier expectation of this sector becoming a substantial job engine [39] [40]. Office and administration jobs, in particular, followed by service and sales occupations, are those with the highest probability of computerization [22]. However, methodological concerns have manifested around their approach, questioning the validity of the results [41]. For one, [22] over-estimated the risk of automation in their sample of occupations, pushing the overall proportion of jobs at risk upwards. To name a few key arguments, firstly, the authors assumed that if an occupation could be computerized then all jobs in that occupation would be destroyed. This is a rather reductionist view since in most cases if technology were to substitute for labor, it is unlikely that all jobs in that respective job family would be lost. Secondly, technical feasibility does not always imply economic feasibility [42]. That is, for human jobs to be substituted for machines, the change in the production mix must be comparably more profitable for firms than previous labor intensive production processes. Finally, preferences for human interaction in certain industries, such as elderly care and education, might prevent certain occupations from being automated [43]. 
Transportation is another services sector where many jobs run the risk of being automatized. Self-driving cars and trucks are being developed rapidly, and are expected to fully penetrate society by 2026 [44]. Many of the associated jobs reside in the public-sector and tend to be well-paid while offering easy labor market access even with low skills. The automation of these jobs could therefore bring sizeable consequences for both, the number of jobs and income inequality. For example, the automation of transportation means that 13 per cent of the economically active global population could lose their job, adding, on average, 13 percentage points to any country's unemployment rate [43]. At the same time, manufacturing sectors remain highly susceptible to automation, including in emerging economies. For instance, in ASEAN countries, sectors such as electrical appliances and electronics might make redundant over 60 per cent of workers in Indonesia, Philippines, Thailand and Vietnam. Moreover, over 80 per cent of workers in the Textile, Clothing and Footwear industry can be substituted by automation in Cambodia and Vietnam [29].

The agricultural sector is also likely to be affected in the near future, particularly in developed countries. In the United States, for instance, agriculture, forestry, fishing and hunting is expected to eliminate 223,000 jobs by 2022 [45]. Many commentators already are looking forward to the Internet of Things, and scientists have started applying this concept to agricultural processes and developing an Internet of Living Things [46] [47]. This contains sophisticated sensors embedded in fields, water way, and irrigation systems that connect with machine-learning systems which are set to maximize production in an environmentally friendly manner [47]. Many of these future agricultural technologies require little labor: The Japanese company Spread, for instance, has recently announced that modern technologies will carry out all but one activity required to grow tens of thousands of lettuce each day in its indoor automated farm [47] [48].

\subsection{Zambian Case on Unemployment and Job Creation}

According to the Seventh (7) National Development Plan of 2017, reveals that in 2014, more than 80 percent of the employed Zambians were from the informal sector [49]. However, the sector recorded low levels of productivity, capital investments and technology, which in turn offered limited prospects to contribute to national development and ultimately improve the standard of living of the majority of the people. The SNDP highlights the following challenges [49]:

- Zambia records reduced labor productivity and one of the binding constraints to raising low productivity has been weak physical capital, which are the resources that people have in savings and investments as well as lack of access to technology to bring about higher production outputs within a short period of time.

- This is exacerbated by weak human capital as a result of low levels of productive skills in specialized production lines required to improve efficiency in the production of goods and services. 
- The overall unemployment rate in 2014 was 7.4 percent of the total labor force comprising of urban unemployment rate at 11.5 percent and rural unemployment rate at 4.2 percent.

- Young unemployment remained one of the biggest challenges for the Country. Of the 3,812,923 youths in the labor force, 400,810 were unemployed, representing a youth unemployment rate of 10.5 percent. The male youth unemployment rate was higher at 12.2 percent than the female youth unemployment rate at 9.1 percent. The rural youth unemployment rate was 6.4 percent, compared to 15.2 urban youth unemployment rate.

- The country still lacks adequately skilled workers. The major challenge that the country faces is that most workers enter the labor force after dropping out of school and without attaining basic numeracy, ICT and literacy skills.

- The majority of the people working in the informal sector are classified as working poor with low levels of income, limited or no access to social security and other core labor standards as prescribed by the International Labor Organization.

- In addition, a significant number of the working population is self-employed, mainly in subsistence agriculture or small-scale and often fragile businesses.

The Government will in an effort to improve the skills of the workforce intends to promote a bias towards training programmes and investments in technical and vocational skills that tend to promote self-employment, especially among the youth [49]. This is planned so because it is believed that the vulnerability of the economy should be tackled at various fronts, one of which should include focusing on the country's human capital, especially the youth, to effectively participate in employment opportunities that may arise from increased economic activities in sectors that will drive economic diversification [49]. Furthermore, efforts will be made to match investment prospects that tend to define future labor characteristics, to the supply of skills [49]. The Government in the 7 NDP period facilitate investment in generating information on job prospects and strengthen the interface between job seekers and the market [49]. This expected to enhance labor productivity since increased productivity results in the production of more goods and services for the same amount of relative work and this helps in transforming people's living standards [49]. There is a positive correlation between increase in physical capital, technology and human capital with an increase in productivity [49].

\section{Summary and Identified Gaps in the Literature}

This paper looked at Human Capital Management, the future of work and looked at the Zambian scenario:

1) The first subsection in Human Capital Management contains three parts namely, definition of human capital, human capital theory and the empirical studies of human capital management. Various scholars and researchers have failed to come up with a consensus definition of human capital management as of today. The concept of human capital deals is said to be added value which in- 
dividuals provide to distinguish one organization from another and this is considered as a real competitive advantage. Human capital is the knowledge, skills, competencies and the attributes that could be collected in individuals and makes it easy to achieve personal, economic and social success. The second part traces the roots of the theory of human capital from the field of macroeconomic development theory and argues that there are different kinds of capitals that include schooling, a computer training course, and expenditures on medical care. Classical Economic Theory's perspective, considers labor as a commodity that is traded by way of purchase and sale. It also perceives labor as something that is exploited by capital. However, contrary to the traditional meaning associated with the term labor, human capital viewed labor in terms of knowledge, expertise, and skill, one accumulates through education and training hence the emphasis is on the social and economic importance of human capital theory. Of all capital the organization might have, the most valuable of all capital is that investment in human being. Education and training are viewed to be the most important investment in human capital. The third and final part look at empirical studies that have been carried out and have revealed that there is a relationship between Human Capital Management and performance, innovation and employee engagement as highlighted.

2) A review of literature on the future of work notes that the last few years have seen an emergency of enormous amount of literature that in the context of the "Future of work" hat has fuelled debate among Academics' think tanks and policy makers. However, these rich discussions on how the future of work might look like and how this could be shaped, have failed to come up with a universally accepted definition of what exactly the "future of work" could encompass and what could be the most relevant drivers that could influence future jobs and wages. The debate on the future of work has however brought out the following points:

- Whether enough jobs would be created in the coming years for all those who would be seeking to work.

- Researchers and Academicians are less convinced and believe innovation has, in fact, peaked and at the same time, there are additional drivers of change such as climate change and demographic shifts that are also set to influence the number of jobs in the future. Most observers seem to agree on the likelihood of acceleration job destruction under the impression of current technological changes.

- In contrast, little is known about the potential for the creation of new jobs. For such new jobs to appear, many comment on the need for new markets to be developed and regulated, in particular in the green economy, care and personal services sectors, or an augmented public sector in areas where currently no profitable activities exist.

- Number of jobs might fall faster than the global labor force when existing jobs are substituted by automation and other systems operated by artificial intelligence. 
- Machines, robots and computers will increasingly have an absolute advantage over labor and not only a comparative one. A growing body of researchers argues that technological progress in robotics and automation would lead to net job losses or lower wages as these advancements increasingly substitute for labor. For example, job losses are expected to concentrated among low and middle-skilled (white-collar) administrative and routine jobs, such as bookkeeping, product testing and machine operators, leading to a rise in job polarization in advanced countries and a large number of developing economies. The potential productivity and producer welfare gains are believed to act as a catalyst for such changes in production processes.

- Companies with more automated activities are 6 times more likely to experience revenue growth of more than 15 per cent compared to companies with low automation.

- Automation might also cause jobs to be re-shored from developing countries to advanced economies. The increasing use of robots in developed countries together with new production techniques that demand a sophisticated level of skills will reduce labor-cost advantages of producing in developing countries which might lead to a displacement of employment from developing to developed countries.

- Job creation in the services sector is mostly under threat from automation despite the earlier expectation of this sector becoming a substantial job engine. Office and administration jobs, in particular, followed by service and sales occupations, are those with the highest probability of computerization.

- Transportation is another services sector where many jobs run the risk of being automatized. Self-driving cars and trucks are being developed rapidly, and are expected to fully penetrate society by 2026 . The automation of these jobs could therefore bring sizeable consequences for both, the number of jobs and income inequality.

- The automation of transportation means that 13 per cent of the economically active global population could lose their job, adding, on average, 13 percentage points to any country's unemployment rate.

- Manufacturing sectors remain highly susceptible to automation, including in emerging economies. In ASEAN countries, sectors such as electrical appliances and electronics might make redundant over 60 per cent of workers in Indonesia, Philippines, Thailand and Viet Nam. Moreover, over 80 per cent of workers in the Textile, Clothing and Footwear industry can be substituted by automation in Cambodia and Viet Nam.

- The agricultural sector is also likely to be affected in the near future, particularly in developed countries. In the United States, for instance, agriculture, forestry, fishing and hunting is expected to eliminate 223,000 jobs by 2022 .

3) The Seventh (7) National Development Plan (2017), reveals that in 2014, more than 80 percent of the employed Zambians were from the informal sector. This has been attributed to low levels of productivity recorded. The SNDP attributes this reduced labor to weak physical capital, which are the resources 
that people have in savings and investments as well as lack of access to technology to bring about higher production outputs within a short period of time. This is exacerbated by:

- Weak human capital as a result of low levels of productive skills in specialized production lines required to improve efficiency in the production of goods and services.

- Young unemployment remained one of the biggest challenges for the Country.

- The country still lacks adequately skilled workers. The major challenge that the country faces is that most workers enter the labor force after dropping out of school and without attaining basic numeracy, ICT and literacy skills.

- The majority of the people working in the informal sector are classified as working poor with low levels of income, limited or no access to social security and other core labor standards as prescribed by the International Labor Organization.

- In addition, a significant number of the working population is self-employed, mainly in subsistence agriculture or small-scale and often fragile businesses.

4) The existing literature on the human capital management, the future of work and the Zambian case on job creation and unemployment, covers a wide range of topics. Investment in the human capital enhances performance, employee engagement, innovation and labor productivity. However, it has been observed that the future of work; technology advancement, automation in the transportation, manufacturing sector and agriculture sector might disrupt economic and social activities in developing countries including Zambia by 2026 . Nevertheless, despite this wealth of existing studies some important gaps remain that should be addressed in future research:

- Reduction on poverty levels, little is known about the margin by which margin poverty levels both in rural and urban areas will be reduced by 2021 considering that technological advancements and automation are expected to alter the way of doing business in service sector: Transport Sector, Manufacturing Sector and also the Agriculture sector by 2026.

- Develop strategies on human capital development to address the challenges associated with low labor productivity and how technological advancements, automation in the service sector (transportation), manufacturing sector and agriculture sector will sustain jobs that Zambian Government will have created for the locals by the year 2026 .

- Develop strategies on human capital development which will ensure that most workers that enter the labor force after dropping out of school, attain basic numeracy, ICT and literacy skills by 2026 .

- Explore measures to address wage inequality issues in view of off loading robots and use of articial intelligences on the Zambian market which could have potential to widen the gap between highly skilled expatriates and local Zambians. 


\section{Conflicts of Interest}

The authors declare no conflicts of interest regarding the publication of this paper.

\section{References}

[1] Goodarzi, M.R., Goodarzi, A. and Goodarzi, E. (2015) The Role of Human Capital Development and Innovation in Healthcare Organizations of Markazi Province in Iran. Journal of Health Management and Informatics, 3, 1-6. https://www.ingentaconnect.com/content/doaj/23221097/2016/00000003/00000001/ $\underline{\operatorname{art} 00004}$

[2] Hassan, R. (2016) The Role of Human Capital Management in Enhancing Engagement and Retention among Top Talent in Organization: A Critical Literature Review. Journal of Emerging Economies and Islamic Research, 4, 55-67.

http://www.docucu-archive.com/Vol.-2\%2C-No.-1-Human-Resource-Decision-Sup port.pdf

[3] Marimuthu, M., Arokiasamy, L. and Ismail, M. (2016) Human Capital Development and Its Impact on Firm Performance Evidence from Developmental Economies. The Journal of International Social Research, 8, 265-272.

http://www.jeeir.com/v2/images/2016V4N4/JEEIR2016_SI_5.pdf

[4] Rachel Grace Nicol Keita (2013) The Impact of Human Capital Management on Operational Performance at the Gambia National Water and Electricity Company (NAWEC). School of Business, KNUST, College of Art and Social Sciences. 1-89. (Unpublished)

http://ir.knust.edu.gh/bitstream/123456789/7750/1/RACHEL\%20GRACE\%20NICO L-KEITA.pdf

[5] Balliester, T. and Elsheikhi, A. (2018) The Future of Work: A Literature Review. Research Department Working Paper No. 29, ILO, 1-62.

[6] ILO Inception Report (2017)

[7] Alika, Joseph, I. and Aibieyi, S. (2014) Human Capital: Definitions, Approaches and Management Dynamics. Journal of Business Administration and Education, 5, 55-78. http://www.infinitypress.info/index.php/jbae/article/viewFile/352/283

[8] Kucharcikova, A., Tokarcikova, E. and Blaskova, M. (2014) Human Capital Management: Aspect of the Human Capital Efficiency in University Education. Global Conference on Contemporary Issues in Education, Globe EDU 2014. 48-60. http://www.infinitypress.info/index.php/jbae/article/viewFile/352/283

[9] Hossain, U. and Roy, I. (2016) Human Capital Management: The New Competitive Approach. International Journal of Economics, Commerce and Management, IV, 1020-1054. http://ijecm.co.uk/wp-content/uploads/2016/05/4560.pdf

[10] Hallward-Driemeier, M. and Nayyar, G. (2017) Trouble in the Making? The Future of Manufacturing-Led Development. World Bank, Washington, DC. https://doi.org/10.1596/978-1-4648-1174-6

[11] Fine, J. (2015) Alternative Labour Protection Movements in the United States: Reshaping Industrial Relations? International Labour Review, 154, 15-26. https://doi.org/10.1111/j.1564-913X.2015.00222.x

[12] Boroujerdi, R.Y., Siadat, S.A., Hoveida, R. and Khani, S. (2014) The Study of the Nature of Human Capital Management and Its Strategic Role in Achieving Competitive Advantage for the Organization. International Journal of Scientific and Research Publications, 4, 1-4.

[13] Baron, A. and Armstrong, M. (2008) Human Capital Management, Achieving 
Added Value through People. Kogan Publishers, London.

[14] Hietela, K. (2006) General Framework for Long-Term Social Impact Evaluation of an Employment Strategy Sub-Reports: Human Capital, USA, Ministry of Labour.

[15] Menzies, L. (2003) Unlocking the Human Potential for Public Sector Performance. Expert Group Meeting, United Nations, Florence, Italy, May 62006.

[16] Kordestani, G.R. (2008) Measurement and Reporting of Human Capital. Hesabras Journal, 41, 32-26.

[17] Schultz, T.W. (1993) The Economic Importance of Human Capital in Modernization. Education Economics, 1, 13-19. https://doi.org/10.1080/09645299300000003

[18] Becker, G.S. (1993) Human Capital: A Theoretical and Empirical Analysis with Special Reference to Education. 3rd Edition, University of Chicago Press, Chicago. https://doi.org/10.7208/chicago/9780226041223.001.0001

[19] Alnachef, T.H. and Alhajjar, A. (2015) Effect of Human Capital on Organizational Performance: A Literature Review. International Journal of Science and Research, 1154-1158.

[20] Brynjolfsson, E. and McAfree, A. (2014) The Second Machine Age. MIT, Cambridge.

[21] Gordon, R. (2000) Does the "New Economy" Measure up to the Great Inventions of the Past? Working Paper No. 7833, NBER, Cambridge.

[22] Frey, C. and Osborne, M. (2013) The Future of Employment: How Susceptible Are Jobs to Computerisation? Working Paper, University of Oxford, Oxford.

[23] Arntz, M., et al. (2016) The Risk of Automation for Jobs in OECD Countries. OECD Social, Employment and Migration Working Papers, OECD Publishing, Paris.

[24] Manyika, J., et al. (2017) A Future That Works: Automation, Employment and Productivity. McKinsey \& Company, New York.

[25] Daheim, C. and Wintermann, O. (2017) 2050: Die Zukunft Der Arbeit. Bertelsmann Foundation, Gutersloh.

[26] World Bank (2016) World Development Report 2016: Digital Dividends. Washington DC.

[27] Deloitte (2014) Agiletown: The Relentless March of Technology and London's Response. Futures, London.

[28] International Labour Organisation (ILO) (2016) ASEAN in Transformation: How Technology Is Changing Jobs and Enterprises. Geneva.

[29] UK Commission for Employment and Skills (2014) The Future of Work: Jobs and Skills in 2030. London.

[30] McKinsey \& Company (2015) The Four Global Forces Breaking All the Trends. New York.

[31] Berger, R. (2016) The Industrie 4.0 Transition Quantified. Munich.

[32] PwC (2017) The Long-View: How Will the Global Economic Order Change by 2050. London.

[33] Chang, J. and Phu, H. (2016) The Future of Jobs at Risk of Automation in ASEAN. ILO Working Paper No. 9, ILO, Geneva.

[34] Bowles, D.C., Butler, C.D. and Friel, S. (2013) Climate Change and Health in Earth's Future. https://agupubs.onlinelibrary.wiley.com/doi/abs/10.1002/2013EF000177

[35] Bruegel Blog (2014) 
http://bruegel.org/2014/07/chart-of-the-week-54-of-eu-jobs-at-risk-of-computerisat ion/

[36] Cohen, A., et al. (2016) Benchmarking Global Production Sourcing Decisions: Where and Why Firms Offshore and Reshore. Stanford University Graduate School of Business Research Paper No. 16-28, Stanford.

[37] De Backer, K., et al. (2016) Reshoring: Myth or Reality? OECD Science, Technology and Industry Policy Papers, OECD, Paris.

[38] United Nations Conference on Trade and Development (UNCTAD) (2016) Robots and Industriaization in Developing Countries. Policy Brief No. 50, Geneva.

[39] Orr, J. and Rosen, R. (2000) Current Issues in Economics and Finance. Current Issues in Economics and Finance, 6, 1-6.

[40] Bennington, J. and Chamberlain, J. (1989) Beyond FTS2000: A Program for Change. National Academies Press, Washington DC.

[41] Borland, J. and Coelli, M. (2017) Are Robots Taking Our Jobs? The Australian Economic Review, 50, 377-397. https://doi.org/10.1111/1467-8462.12245

[42] Acemoglu, D. and Fabrizio, Z. (2001) Productivity Differences. The Quarterly Journal of Economics, 115, 563-606. https://doi.org/10.1162/00335530151144104

[43] Finkel, A. (2017) Finkel's Law: Robots Won't Replace Us Because We Still Need That Human Touch. The Conversation, London.

[44] Estevadeordal, A., et al. (2017) The Future of Work in Latin American Integration 4.0. Integration and Trade Journal, 21.

[45] West, D. (2015) What Happens If Robots Take the Jobs? The Impact of Emerging Technologies on Employment and Public Policy. Brookings, Washington DC.

[46] Clark, L. (2017) Oxford Nanopore: We Want to Create the Internet of Living Things.

http://www.wired.co.uk/article/clive-brown-oxford-nanopore-technologies-wired-h ealth-2015

[47] Fraser, E. and Charlebois, S. (2016) Automated Farming: Good News for Food Security, Bad News for Job Security?

[48] EcoWatch (2015) World's First Robotic Farm to Produce 30,000 Heads of Lettuce per Day. Ohio.

[49] (2017) Seventh National Development Plan. http://www.mndp.gov.zm/download/7NDP.pdf 